\title{
Microbial Air Contamination in An Intensive Care Unit
}

\author{
Chih-Yi Chang ${ }^{1}$, Liang Tseng ${ }^{2}$, Lung-Shih Yang ${ }^{3}$ \\ ${ }^{1}$ Civil and Hydraulic Engineering, Feng Chia University, Taiwan \\ ${ }^{2}$ Department of Architecture, Feng Chia University, Taiwan \\ ${ }^{3}$ Department of Land Management, Feng Chia University, Taiwan
}

\begin{tabular}{l} 
Article Info \\
\hline Article history: \\
Received Jun 04, 2015 \\
Revised Aug 20, 2015 \\
Accepted Aug 30, 2015 \\
\hline
\end{tabular}

Keyword:

Indoor air quality

Intensive care unit

Microbial air contamination

Unit layout

\begin{abstract}
Unit layout affects every aspect of intensive care services, including patient safety. A previous study has shown that patients admitted to beds adjacent to the sink and to the door of a large bayroom had the highest number of positive blood cultures and the highest blood culture incidence density, respectively. The present study measures microbial air contamination in a medical intensive care unit of a medical center in central Taiwan. Of the 17 rooms, 8 rooms with distinct physical environmental characteristics were selected. Sampling tests were conducted between December 2013 and February 2014 with a microbial air sampler (MAS-100NT). TSA was used for bacteria collection and DG18 for fungi collection. The overall average bacterial and fungal concentrations were $83 \mathrm{CFU} / \mathrm{m}^{3}$ and $69 \mathrm{CFU} / \mathrm{m}^{3}$, respectively. The ranges were between $8-354 \mathrm{CFU} / \mathrm{m}^{3}$ and $0-1468 \mathrm{CFU} / \mathrm{m}^{3}$, respectively. A significant difference was found in the bacterial concentration $(p=.005)$ between different room locations. The highest concentration was found in the rooms located at the front end of the circulation $\left(99 \mathrm{CFU} / \mathrm{m}^{3}\right)$, while the lowest was found in the rooms located at the rear end of the circulation $\left(55 \mathrm{CFU} / \mathrm{m}^{3}\right)$. Differences in fungal concentrations for different room locations did not reach statistical significance. In addition, differences in bacterial and fungal concentrations for rooms with different sink locations did not reach statistical significance. Even though the microbial concentrations generally complied with standards, the results may help designers and hospital administrators develop a healthier environment for patients.
\end{abstract}

Copyright (C) 2015 Institute of Advanced Engineering and Science. All rights reserved.

\section{Corresponding Author:}

Chih-Yi Chang,

Ph.D. Program in Civil and Hydraulic Engineering,

Feng Chia University,

No. 100, Wenhwa Rd., Seatwen, Taichung, Taiwan 40724, R.O.C.

Email: evechang117@gmail.com

\section{INTRODUCTION}

Intensive care units (ICU) are specialized divisions of a hospital which provide close monitoring and intensive care for patients with life-threatening conditions. As the most fundamental physical design feature, unit layout affects every aspect of intensive care services, including patient safety [1], [2]. There are 7 types of unit layout: open or Nightingale type, corridor or continental type, duplex or Nuffield type, racetrack or double corridor type, courtyard type, cruciform or cluster type, and radial type [3]. However, there is no single best solution for an ICU layout [1], [4].

ICUs are also a type of biological clean unit. Microbial contamination is the most influential parameter among indoor air pollutants in health care environments. Airborne bacteria and fungi are potential agents for infectious diseases, and their concentrations must meet certain requirements for the safety of patients, medical staff, and visitors. Previous studies have shown that air temperature, realtive humidity [5], ventilation systems [6],[7], outdoor penetration, and occupant density [5],[7], are the main factors affecting 
concentrations of airborne bacteria and fungi. Bracco et al. found that patients admitted to beds adjacent to the sink and to the door of a large bayroom had the highest number of positive blood cultures and the highest blood culture incidence density, respectively [8]. Even though bed-to-bed comparison did not reach statistical significance, the issue of bed location, sink location and the concentration of airborne bacteria and fungi is still worth investigating. Therefore, the present study measures airborne bacterial and fungal concentrations in an ICU. The key objectives of the study included: 1) to measure bacterial and fungal concentrations against current standards; 2) to evaluate the impact of room locations and sink locations on bacterial and fungal levels.

\section{RESEARCH METHOD}

\subsection{Sampling site}

The study took place in an adult medical intensive care unit at a 1500-bedded medical center in central Taiwan. The layout of the unit is the modified open or Nightingale type, which the unit can be divided into two areas, the patient area and the support services area. The patient area has a central nurse station and patient beds on the perimeter. The support services area is located adjacent to the patient area, and there is a corridor connecting the two areas. From the 17 patient rooms in the unit, 8 sampling rooms were selected on the basis of room locations and sink locations as shown in Figure 1. With regard to room locations, Room A, $\mathrm{D}$, and $\mathrm{F}$ are located at a turn of the circulation; Room B and $\mathrm{H}$ are located at the front end of the circulation; Room $\mathrm{C}$ and $\mathrm{G}$ are located in the middle of the circulation. Compared to other selected rooms, the entrance of Room E is slightly off the main circulation. With regard to sink locations, Room A and E have a corner sink installed inside the patient room as shown in Figure 2; the other 6rooms share sinks with an adjacent room as shown in Figure 3. The average dimensions of the selected rooms are 3.5m (L) x3.75m (W) x 3m (H), giving an average volume of $39.375 \mathrm{~m}^{3}$.

Air ventilation is provided by a central air conditioning system with HEPA filter installed. The air change rate is $5.2 / \mathrm{h}$. There is a ceiling-mounted air outlet and wall-mounted return air inlet in every patient room. Unit maintenance includes a daily high-level-disinfection procedure using sodium hypochlorite, monthly floor waxing, and a sterilization procedure with sodium hypochlorite and ultraviolet radiation on changes of occupant.

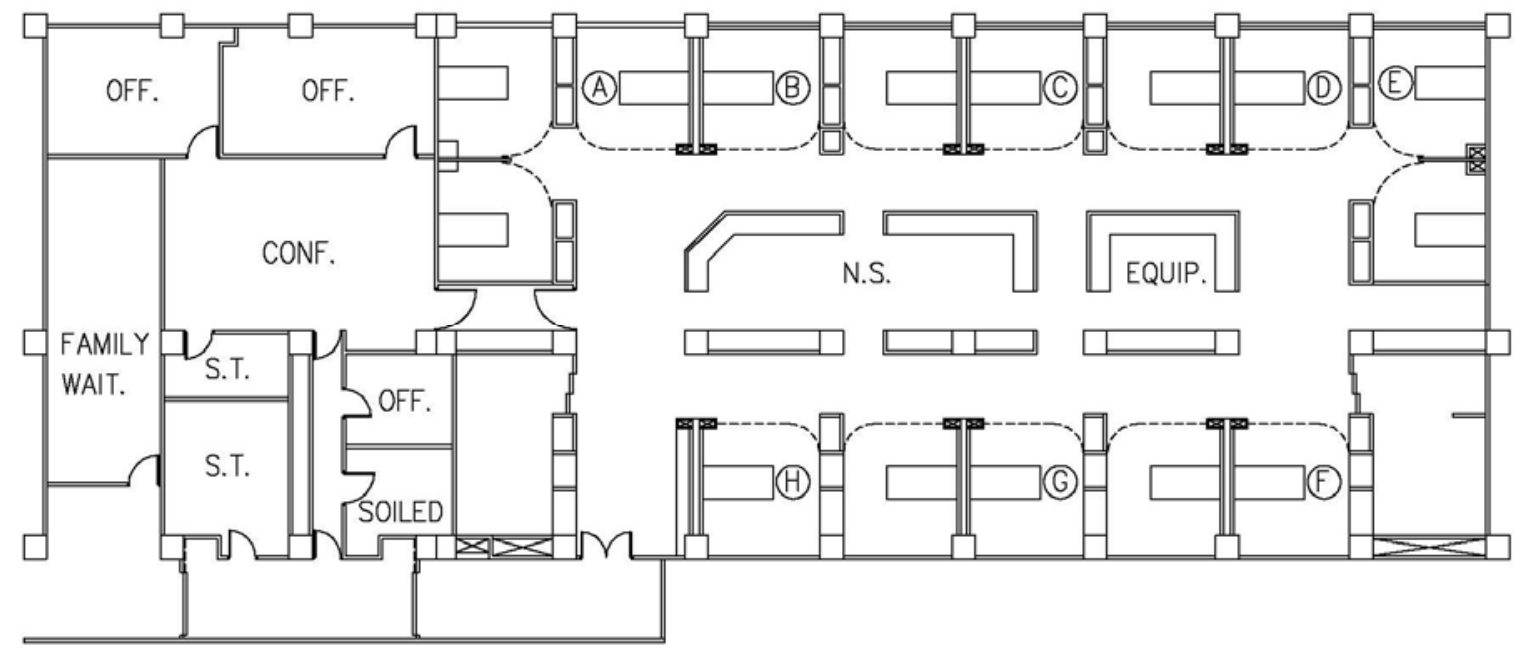

Figure 1. Room layout and sampling rooms in the medical ICU

\subsection{Sampling procedure}

Microbial air samples from the 8 selected rooms were collected between December, 2013 and February, 2014. During the sampling period, a room was randomly picked and monitored for two consecutive days every week (mostly Monday and Tuesday). At each sampling point, air samples were taken at 6 different time slots each day: 9:00, 11:00, 13:00, 15:00, 17:00 and 19:00. A microbial air sampler - MAS100NT was used for airborne bacteria and fungi collection. The device was operating at $100 \mathrm{~L} / \mathrm{min}$ for 2.5 
minutes. Tryptic Soy Agar (TSA) was used for bacteria collecting and culturing. Dichloran Glycerol-18 (DG18), which is more effective in collecting fungal colonies in a central-air-conditioning hospital setting [9], was used for fungi collecting and culturing. Between measurements, the sampler was cleaned with $75 \%$ ethanol. After field sampling, TSA agar plates were incubated at $30^{\circ} \mathrm{C}$ for 2 days, and DG18 agar plates were incubated at $25^{\circ} \mathrm{C}$ for 5 days. Gram's stain was performed to classify bacteria and fungi during colony counts as shown in Figure 4.

The air sampler was factory calibrated beforethe sampling test. To ensure patients could get proper rest and to avoid disturbing staff activities, the sampler was placed at the end of the patient bed as shown in Figure 5. The inlet of microbial air sampler was set at $100 \mathrm{~cm}$ above the floor, the level of the breathing zone of a lying patient.

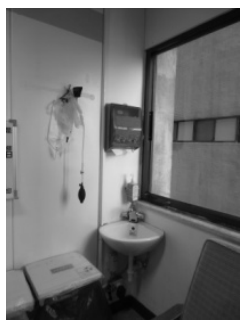

Figure 2. Corner sink

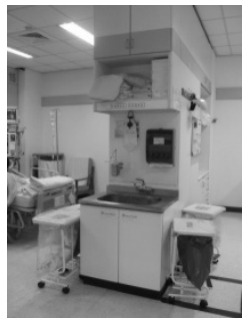

Figure 3. Shared sink

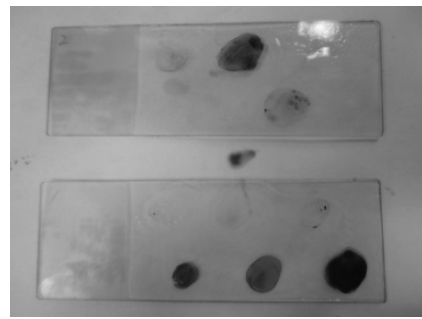

Figure 4. Gram's stain

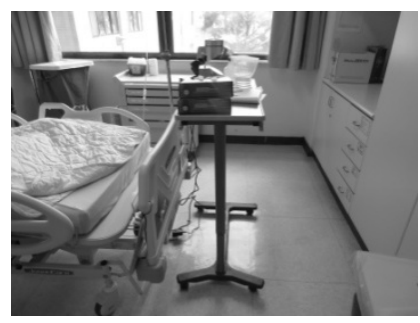

Figure 5. Sampling point

\section{RESULTS AND DISCUSSION}

\subsection{Airborne bacterial and fungal concentrations}

The highest value of bacterial concentrationinthe sampling rooms wasbelow $1500 \mathrm{CFU} / \mathrm{m}^{3}$ as shown in Table 1, the maximum value legislated by the Environmental Protection Administration (EPA) in Taiwan. The total bacterial concentration was $83 \mathrm{CFU} / \mathrm{m}^{3}$, which also met the standard set by the Korean Ministry of Environment for healthcare facilities $\left(800 \mathrm{CFU} / \mathrm{m}^{3}\right)$ and the Excellent Class of Indoor Air Quality in Offices and Public Places issued by the Environmental Protection Department in Hong-Kong (500 CFU $/ \mathrm{m}^{3}$ ). The average values for Room A-F were below $100 \mathrm{CFU} / \mathrm{m}^{3}$, categorizing them as clean according to the criteria for indoor air quality defined by the Spanish Association of Hospital Engineering (AEIH). The average values for Room $\mathrm{G}$ and $\mathrm{H}$ were below $200 \mathrm{CFU} / \mathrm{m}^{3}$, meeting the criteria for acceptable indoor air quality in hospital environments. The highest average was found in Room G with concentration value of $117 \mathrm{CFU} / \mathrm{m}^{3}$, followed by Room $\mathrm{H}$ and Room B with concentration value of $104 \mathrm{CFU} / \mathrm{m}^{3}$ and $95 \mathrm{CFU} / \mathrm{m}^{3}$, respectively. The lowest was found in Room $\mathrm{F}$ with a concentration value of $53 \mathrm{CFU} / \mathrm{m}^{3}$.

The total bacterial concentration found in this study was lower than the results reported by

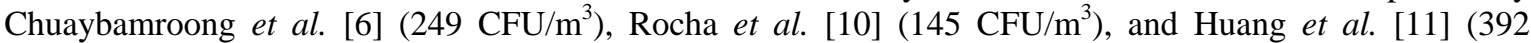
$\mathrm{CFU} / \mathrm{m}^{3}$ and $356 \mathrm{CFU} / \mathrm{m}^{3}$ in ICU I and ICU II, respectively, during sampling consistency study). The result was also lower than the average reported by Fumagalli et al. [12], who found a value slightly higher than 250 $\mathrm{CFU} / \mathrm{m}^{3}$ during restrictive visiting periods. The minimum value $\left(8 \mathrm{CFU} / \mathrm{m}^{3}\right)$ of bacterial concentration was found in Room $\mathrm{F}$ and the maximum value $\left(354 \mathrm{CFU} / \mathrm{m}^{3}\right)$ was found in Room $\mathrm{B}$. These findings were consistent with the results obtained by Li \&Hou [13], which ranged between 1-423 CFU $/ \mathrm{m}^{3}$ in ICUs.

The averages of bacterial levels at 9:00, 11:00, 13:00, 15:00, 17:00 and 19:00 time slots were 145 $\mathrm{CFU} / \mathrm{m}^{3}, 109 \mathrm{CFU} / \mathrm{m}^{3}, 43 \mathrm{CFU} / \mathrm{m}^{3}, 85 \mathrm{CFU} / \mathrm{m}^{3}, 61 \mathrm{CFU} / \mathrm{m}^{3}$ and $46 \mathrm{CFU} / \mathrm{m}^{3}$, respectively. The highest average was found at 9:00, which was the busiest period for caring nurses with tasks included giving bedbaths and oral-rinsing, changing soiled diapers, turning over patients, and administering medications. The second highest average was found at 11:00, which was the time slot right after morning visitation. The lowest average was found at 13:00, which was the quiet period. The bacterial concentration raised again at 15:00, the time slot right after afternoon visitation. And the concentration levels went down at 17:00 and down again at 19:00. The pattern showed close relationship between bacterial concentrations and densities and activities of the sampling site. The result of the Kruskal-Wallis test showed a significant difference in the bacterial concentration between the different time slots $(\mathrm{p}=.000)$.

Although the averages of bacterial concentrations met the requirements, the concentration values found on the first day in Room B $\left(354 \mathrm{CFU} / \mathrm{m}^{3}\right)$, the second day in Room E $\left(206 \mathrm{CFU} / \mathrm{m}^{3}\right)$, the first and the second day in Room G $\left(245 \mathrm{CFU} / \mathrm{m}^{3}\right.$ and $\left.256 \mathrm{CFU} / \mathrm{m}^{3}\right)$ at 9:00, and the first day in Room $\mathrm{G}\left(255 \mathrm{CFU} / \mathrm{m}^{3}\right)$ and the second day in Room $\mathrm{H}\left(214 \mathrm{CFU} / \mathrm{m}^{3}\right)$ at 11:00, were above $200 \mathrm{CFU} / \mathrm{m}^{3}$ (Figure 6). According to the 
logbook, nurses' tasks at 9:00 slot have been mentioned. Moreover, although 11:00 was the time slot right after patient visits, there were no visitors on the first day of Room $\mathrm{G}$ and the second day of Room $\mathrm{H}$ in the morning visiting period. However, at the time of measurement, doctors were present treating patients.

With the exception of Room B, the highest value of fungal concentration in the sampling rooms was under $1000 \mathrm{CFU} / \mathrm{m}^{3}$ as shown in Table 1, the maximum value legislated by the EPA. The total fungal concentration was $69 \mathrm{CFU} / \mathrm{m}^{3}$, which met the UK and Singapore standard of indoor air quality (500 $\mathrm{CFU} / \mathrm{m}^{3}$ ). The average values for Room A and Room C-H were below $100 \mathrm{CFU} / \mathrm{m}^{3}$, indicating a clean state of indoor air. The average value of Room B was below $200 \mathrm{CFU} / \mathrm{m}^{3}$, which represented an acceptable state for indoor air. The highest average was found in Room B with concentration value of $162 \mathrm{CFU} / \mathrm{m}^{3}$, followed by Room E and Room D with concentrations of $77 \mathrm{CFU} / \mathrm{m}^{3}$ and $74 \mathrm{CFU} / \mathrm{m}^{3}$, respectively. The lowest average was found in Room $\mathrm{F}$ with a concentration value of $16 \mathrm{CFU} / \mathrm{m}^{3}$. It was worth noting that the standard deviations of Room B, D, E and G were higher than the average values, which exhibited considerable variations of fungal levels in these four rooms.

Table 1. Bacterial and fungal concentrations $\left(\mathrm{CFU} / \mathrm{m}^{3}\right)$

\begin{tabular}{|c|c|c|c|c|c|c|c|c|}
\hline \multirow{2}{*}{ Room } & \multicolumn{4}{|c|}{ Bacterial concentration } & \multicolumn{4}{|c|}{ Fungal concentraion } \\
\hline & $\mathrm{N}$ & Mean(SD) & Min & Max & $\mathrm{N}$ & Mean(SD) & Min & Max \\
\hline $\mathrm{A}$ & 12 & 69(33.99) & 36 & 136 & 12 & 65(56.69) & 8 & 188 \\
\hline B & 12 & $95(87.80)$ & 32 & 354 & 12 & 162(413.11) & 4 & 1468 \\
\hline $\mathrm{C}$ & 12 & $70(31.52)$ & 26 & 142 & 12 & $52(37.49)$ & 8 & 114 \\
\hline $\mathrm{D}$ & 12 & $57(50.64)$ & 16 & 196 & 12 & $74(76.28)$ & 10 & 238 \\
\hline $\mathrm{E}$ & 12 & $89(66.84)$ & 16 & 206 & 12 & $77(90.71)$ & 0 & 252 \\
\hline $\mathrm{F}$ & 12 & $53(32.51)$ & 8 & 124 & 12 & $16(8.67)$ & 4 & 32 \\
\hline G & 11 & 117(97.40) & 14 & 256 & 12 & 49(88.73) & 0 & 310 \\
\hline $\mathrm{H}$ & 12 & $104(57.78)$ & 26 & 214 & 12 & $52(48.03)$ & 8 & 188 \\
\hline
\end{tabular}

The total fungal concentration found in this study was higher than the results reported by Chuaybamroong et al. [6] (67 CFU/m $\left.\mathrm{m}^{3}\right)$, Rocha et al. [10] (9 CFU/m $\left.\mathrm{m}^{3}\right)$, and Huang et al. [11] (12 CFU/m $\mathrm{m}^{3}$ and $59 \mathrm{CFU} / \mathrm{m}^{3}$ in ICU I and ICU II, respectively, during sampling consistency study). However, the result was lower than the average reported by Fumagalli et al. [12], who found a value between 250 and $300 \mathrm{CFU} / \mathrm{m}^{3}$ during restrictive visiting periods. The minimum value $\left(0 \mathrm{CFU} / \mathrm{m}^{3}\right)$ of fungal concentration was found in Room E and Room G. The maximum value $\left(1468 \mathrm{CFU} / \mathrm{m}^{3}\right)$ was found in Room B, and such a high level was unable to explain at this point. These levels were higher than the results reported by Li \&Hou [13] which were in the range of between 0 and $319 \mathrm{CFU} / \mathrm{m}^{3}$ in ICU environments.

The averages of fungal concentrations at 9:00, 11:00, 13:00, 15:00, 17:00 and 19:00 time slots were $62 \mathrm{CFU} / \mathrm{m}^{3}, 70 \mathrm{CFU} / \mathrm{m}^{3}$ (with the value of $1468 \mathrm{CFU} / \mathrm{m}^{3}$ subtracted), $56 \mathrm{CFU} / \mathrm{m}^{3}, 72 \mathrm{CFU} / \mathrm{m}^{3}, 31 \mathrm{CFU} / \mathrm{m}^{3}$ and $31 \mathrm{CFU} / \mathrm{m}^{3}$, respectively. The highest values were found at 11:00 and 15:00, the time slots right after morning and afternoon visiting. The lowest values were found at 17:00 and 19:00. The fungal pattern was different to bacterial pattern. The result of the Kruskal-Wallis test showed no significant difference in the fungal concentration between the different time slots ( $\mathrm{p}>0.05)$.

Although the averages of fungal concentrations met requirements, the concentration values found during the second day in Room D (238 CFU/m $\left.\mathrm{m}^{3}\right)$ at 9:00, the second day in Room B $\left(1468 \mathrm{CFU} / \mathrm{m}^{3}\right)$ and the first day in Room E (252 CFU/m $\left.{ }^{3}\right)$ at 11:00, the first day in Room E $\left(204 \mathrm{CFU} / \mathrm{m}^{3}\right)$ at 13:00, the first day in Room G $\left(310 \mathrm{CFU} / \mathrm{m}^{3}\right)$ at 15:00, were above $200 \mathrm{CFU} / \mathrm{m}^{3}$ as shown in Figure 7 . The activities at the 9:00 slot have been described above. In contrast to the results for bacterial measuring, there were visitors on the second day in Room Band the first day in Room E during the morning visiting period, and the first day in Room $\mathrm{G}$ during the afternoon visiting period. 
Room B

-day $1 \square$ day 2

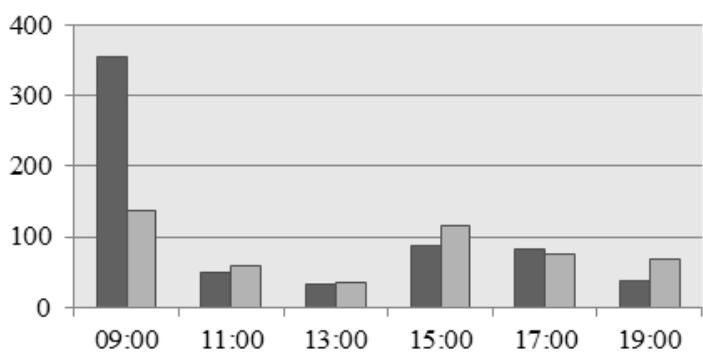

Room G

घday $1 \square$ day 2

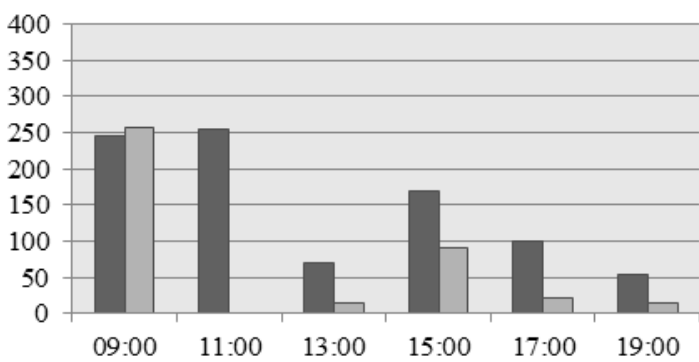

Room E

$\square$ day $1 \square$ day 2

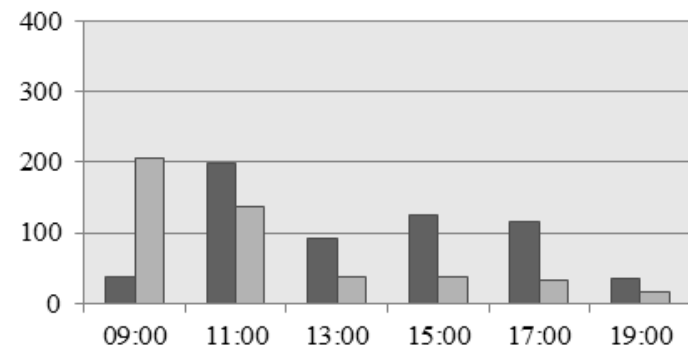

Room H

$\square$ day $1 \square$ day 2

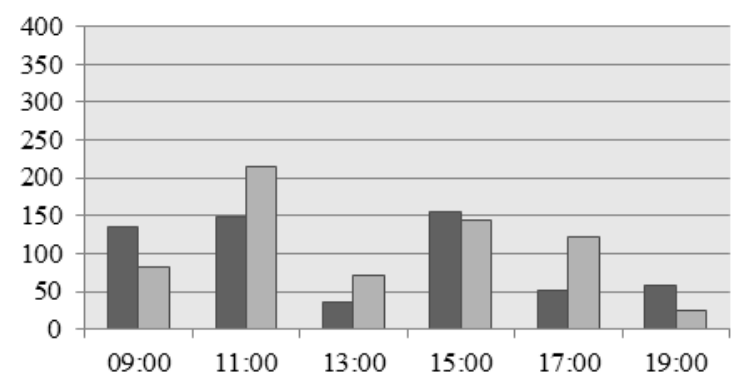

Figure 6. Bacterial concentrations at different time slots $\left(\mathrm{CFU} / \mathrm{m}^{3}\right)$

\section{Room B}

घday $1 \square$ day 2

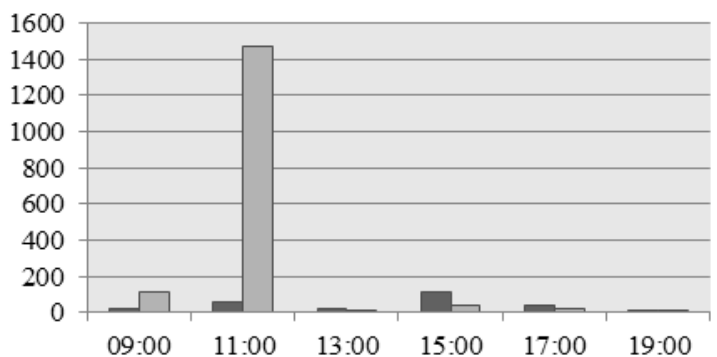

Room E

घday $1 \square$ day 2

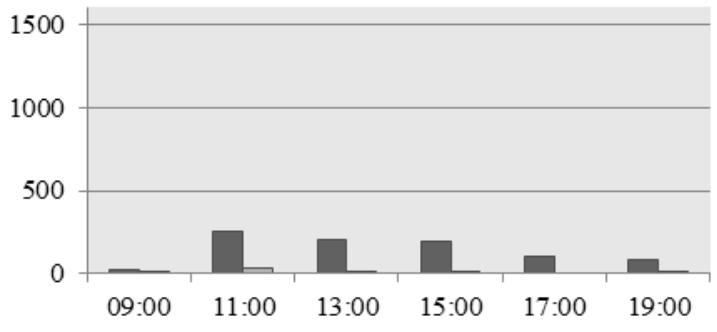

Room D

- day $1 \square$ day 2

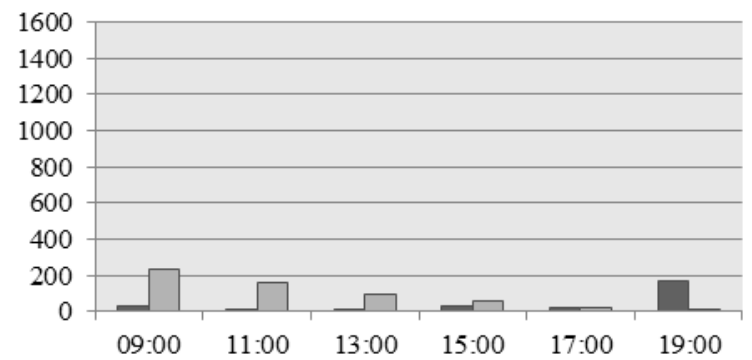

Room G

घday $1 \square$ day 2

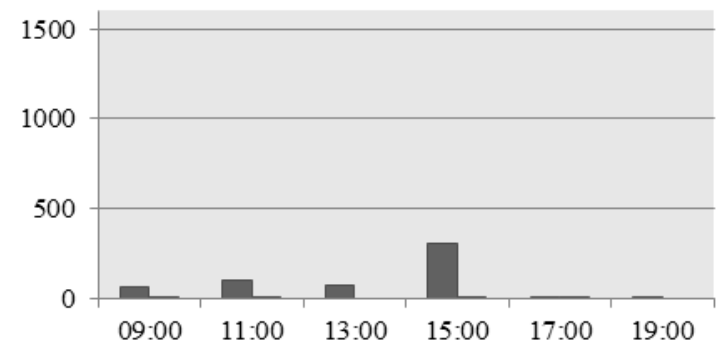

Figure 7. Fungal concentrations at different time slots $\left(\mathrm{CFU} / \mathrm{m}^{3}\right)$ 


\subsection{Patient room locations and sink locations}

Using a Kruskal-Wallis test, significant differences were found in the bacterial and fungal concentrations of the 8 sampling rooms ( $\mathrm{p}=.021$ and $\mathrm{p}=.001$, respectively). The sampling rooms were then divided into 5 categories including front end of the circulation (Rooms $\mathrm{B}$ and $\mathrm{H}$ ), middle of the circulation (Rooms C and G), rear end of the circulation (Rooms D and F), off the circulation (Room E), and facing the entrance (Room A).

The results of the Kruskal-Wallis test showed a significant difference in the bacterial concentration between the different locations of the sampling rooms $(\mathrm{p}=.005)$. The highest concentration was found in the location of the front end of the circulation $\left(99 \mathrm{CFU} / \mathrm{m}^{3}\right)$, followed by middle of the circulation $\left(93 \mathrm{CFU} / \mathrm{m}^{3}\right)$, off the circulation $\left(89 \mathrm{CFU} / \mathrm{m}^{3}\right)$, and facing the entrance $\left(69 \mathrm{CFU} / \mathrm{m}^{3}\right)$. The lowest was found in the rear end of the circulation $\left(55 \mathrm{CFU} / \mathrm{m}^{3}\right)$. However, differences infungal concentrations for different room locations did not reach statistical significance.

With regard to sink locations, the sampling rooms were then divided into 2 categories: patient rooms with corner sink installed (Rooms A and E) and patient rooms with shared sinks (Rooms B, C, D, F, G and $\mathrm{H})$. The result of Kruskal-Wallis test showed no significant difference for both bacterial and fungal concentration, possibly due to the fact that the patient rooms were open in design.

\section{CONCLUSION}

The highest bacterial concentrations in the sampling rooms met the standard set by the EPA in Taiwan. The overall average bacterial concentration was $83 \mathrm{CFU} / \mathrm{m}^{3}$, and bacterial concentrations ranged between 8 and $354 \mathrm{CFU} / \mathrm{m}^{3}$. Although the average bacterial levels represented a clean $\left(10-100 \mathrm{CFU} / \mathrm{m}^{3}\right)$ and acceptable (100-200 CFU $\left./ \mathrm{m}^{3}\right)$ state of indoor air quality in hospital environments according to the criteria defined by the Spanish Association of Hospital Engineering (AEIH), there were 6 measurements over 200 $\mathrm{CFU} / \mathrm{m}^{3}$ during the 9:00 and 11:00 time slots.

With the exception of Room B, the highest value of fungal concentrations in the sampling rooms met EPA standards. The overall average fungal concentration was $69 \mathrm{CFU} / \mathrm{m}^{3}$, and fungal concentrations ranged between 0 and $1468 \mathrm{CFU} / \mathrm{m}^{3}$. Although the average fungal levels represented a clean (10-100 $\mathrm{CFU} / \mathrm{m}^{3}$ ) and acceptable $\left(100-200 \mathrm{CFU} / \mathrm{m}^{3}\right)$ state of indoor air quality in hospital environments, there were 5 measurements over $200 \mathrm{CFU} / \mathrm{m}^{3}$ during the 9:00, 11:00, 13:00 and 15:00 time slots.

With regard to room locations, a significant difference was found in the bacterial concentration $(p=.005)$. The highest concentration was found in the rooms located at the front end of the circulation (99 $\mathrm{CFU} / \mathrm{m}^{3}$ ), while the lowest was found in the rooms located at the rear end of the circulation $\left(55 \mathrm{CFU} / \mathrm{m}^{3}\right)$. Differences in fungal concentrations between room locations did not reach statistical significance. With regard to sink locations, bacterial and fungal concentrations for rooms with different sink locations did not reach statistical significance. Even though the microbial concentrations were generally complied with standards, the results may help designers and hospital administrators develop a healthier environments for patients.

\section{REFERENCES}

[1] Rashid, M., "A decade of adult intensive care unit design: astudy of the physical design features of the best-practice examples", Critical Care Nursing Quarterly, vol/issue: 29(4), pp. 282-311, 2006.

[2] Rashid, M., "Developing scales to evaluate staff perception of the effects of the physical environment on patient comfort, patient safety, patient privacy, family integration with patient care, and staff working conditions in adult intensive care units: apilot study", Critical Care Nursing Quarterly, vol/issue: 30(3), pp. 271-283, 2007.

[3] James, W. P., Tatton-Brown,W., "Hospitals: design and development", London: The Architectural Press, 1986.

[4] Cadenhead, C. D., Anderson, D. C., "Critical care units: Trends in winning designs", World Health Design, vol/issue: 2(3), pp. 72-77, 2009.

[5] Obbard, J. P., Fang, L. S., "Airborne concentrations of bacteria in a hospital environment in Singapore", Water, Air, and Soil Pollution, vol/issue: 144(1-4), pp. 333-341, 2003.

[6] Chuaybamroong, P., Choomseer, P., Sribenjalux, P., "Comparison between hospital single air unit and central air unit for ventilation performances and airborne microbes", Aerosol and Air Quality Research, vol/issue: 8(1), pp. 28-36, 2008.

[7] Qudiesat, K., Abu-Elteen, K., Elkarmi, A., Hamad, M., Abussaud, M., "Assessment of airborne pathogens in healthcare settings", African Journal of Microbiology Research, vol/issue: 3(2), pp. 066-076, 2009.

[8] Bracco, D., Dubois, M. J., Bouali, R., Eggimann, P., "Single rooms may help prevent nosocomial bloodstream infection and cross-transmission of methicillin-resistant staphylococcus aureus in intensive care units", Intensive Care Medicine, vol/issue: 33(5), pp. 836-840, 2007.

[9] Wu, P. C., Su, H. J., Ho, H. M., "A comparison of sampling media for environmental viable fungi collected in a hospital environment", Environmental Research Section A, vol/issue: 82(3), pp. 253-257, 2000. 
[10] Rocha, C. A., Báez, N. A., Villarroel, E. V., Quintero, G. M., "Study of bioaerosols in surgical theaters and intensive care units from a public general hospital", The Journal of Bioscience and Medicine, vol/issue: 2(3), pp. 110, 2012.

[11] Huang, P. Y., Shi, Z. Y., Chen, C. H., Den, W., Huang, H. M., Tsai, J. J., "Airborne and surface-bound microbial contamination in two intensive care units of a medical center in central Taiwan", Aerosol and Air Quality Research, vol/issue: 13(3), pp. 1060-1069, 2013.

[12] Fumagalli, S., Boncinelli, L., Nostro, A. L., Valoti, P., Baldereschi, G., Bari, M. D., Ungar, A., Baldasseroni, S., Geppetti, P., Masotti, G., Pini, R., Marchionni, N., "Reduced cardiocirculatory complications with unrestrictive visiting policy in an intensive care unit: results from a pilot, randomized trial", Circulation, vol/issue: 113(7), pp. 946-952, 2006.

[13] Li, C.S., Hou, P.A., "Bioaerosolcharacteristics in hospital clean rooms", Science of the Total Environment, vol/issue: 305(1-3), pp. 169-176, 2003. 